Proc. Estonian Acad. Sci. Eng., 2006, 12, 4, 388-398

\title{
Comparative study on indentation fracture toughness measurements of cemented carbides
}

\author{
Fjodor Sergejev and Maksim Antonov
}

Department of Materials Engineering, Tallinn University of Technology, Ehitajate tee 5, 19086 Tallinn, Estonia; Fjodor.Sergejev@ttu.ee

Received 2 June 2006, in revised form 10 November 2006

\begin{abstract}
Majority of the fracture toughness studies of metallic materials typically use the Chevron notch technique, compact specimens and round notched tensile specimens. These methods require considerable time for sample preparation and for the notch geometry control. Only a few of them can be applied for cemented carbides due to the very high brittleness of the hard phase. This is why various indentation fracture toughness (IFT) techniques have been developed $\left[^{1,2}\right]$, which are more rapid and simple. Indentation toughness measurements results depend critically on the assumption about the crack type (Palmqvist or median/radial cracks), on the equations used for the calculation of fracture toughness and on the material-dependent and material-independent constants $\left[{ }^{3}\right]$. In the present work a comparative study of IFT calculation methods was carried out to find a reliable technique for studied materials (WC-Co, TiC-Fe/Ni). Several IFT equations for ceramic materials, recommended by standards and publications, were used for the evaluation of the fracture toughness and compared with published conventional fracture toughness data $\left.{ }^{4,5}\right]$. Only few of the equations give reliable estimation of the fracture toughness of cemented carbides.
\end{abstract}

Key words: cermets, hardmetals, fracture toughness, indentation, Palmqvist crack, Vickers hardness.

\section{INTRODUCTION}

In discussions on the hardness and toughness of hardmetals (WC-based) and cermets (TiC-based), it is always assumed that the higher the hardness of the composite material, the lower the fracture toughness, and vice versa. Although this principle is valid in general, a lot of specific aspects must be considered.

The measurements of fracture toughness of cemented carbide are complicated because of very high brittleness of these materials. Sample preparation is timeconsuming and expensive. Methods, based on single edge notched beam (SENB, ASTM STP 1419), single edge precracked beam (SEPB, ISO 15732), the single 
edge V-notched beam (SEVNB, CEN/TS 14425-5:2004), Chevron notched beam, surface crack in flexure (CNB and SCF, ASTM C1421-01b) and other conventional techniques require very precise notch geometry control. Results crucially depend on the surface preparation and on the state of residual stresses.

On the other hand, the indentation fracture toughness technique is much easier to conduct. There is no need for the preparation of the specimens with special geometry and complex notches. Method involves measurements of the lengths of the cracks, which emanate from the corners of Vickers indentation diagonals, of the applied indentation load and of a few material properties such as elasticity modulus and Poisson's ratio. This method is basically used for the measurement of mechanical properties of glasses and ceramics.

The main restrictive factor of the adaptation of IFT for cemented carbides is very high hardness of $\mathrm{WC}-\mathrm{Co}$ and $\mathrm{TiC}-\mathrm{Fe} / \mathrm{Ni}$ cermets. These materials tend to crack only at elevated loads. This complicates cracks length measurements and makes hardly possible to define the crack formation model $\left[{ }^{6,7}\right]$ (Fig. 1). These difficulties led to deviations in the calculation results.

In this paper we compare different IFT measurement methods for cemented carbides.

\section{EXPERIMENTAL PROCEDURE}

Mechanical properties and composition of the studied materials are listed in Table 1. All cemented carbides were produced with conventional press and sinter powder metallurgy according to ASTM B406 at the Powder Metallurgy Laboratory of the Tallinn University of Technology. The cemented carbide specimens were prepared to the following dimensions (width $\times$ height $\times$ length): WC-Co grade $-(5.0 \pm 0.3) \times(5.0 \pm 0.3) \times 19$ and TiC-based ones $-(5.0 \pm 0.3) \times$ $(5.0 \pm 0.3) \times 16, \mathrm{~mm}^{3}$. Specimens were ground to a surface finish of about $1.5 \mu \mathrm{m}$ for WC-Co hardmetals and $2.5 \mu \mathrm{m}$ for TiC-base cermets on four sides (measured along $8 \mathrm{~mm}$ of the specimen by the Surtronic 3+ apparatus, using CR filter). Opposite ground faces were parallel within $0.03 \mathrm{~mm}$.

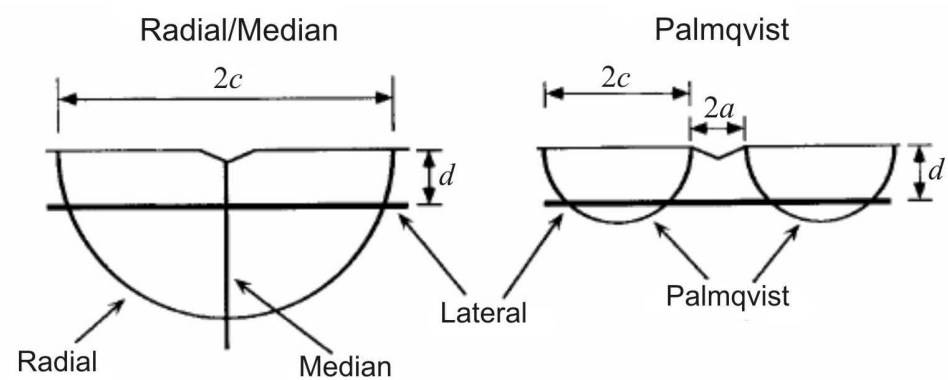

Fig. 1. Principal scheme of the indentation crack geometry. 
Table 1. Mechanical properties of the tested materials

\begin{tabular}{l|c|l|c|c|c}
\hline \multicolumn{1}{c|}{ Grade } & $\begin{array}{c}\text { Carbide, } \\
\text { wt\% }\end{array}$ & Binder composition, structure & $\begin{array}{c}\text { Poisson's } \\
\text { ratio }\end{array}$ & $\begin{array}{c}\text { Vickers } \\
\text { hardness, } \\
H_{V}\end{array}$ & $\begin{array}{c}\text { Elasticity } \\
\text { modulus } E, \\
\mathrm{GPa}\end{array}$ \\
\hline $\mathrm{WC10}$ & $90 \quad \mathrm{Co}(\mathrm{W})$ & $0.23^{*}$ & 1310 & 551 \\
$\mathrm{WC} 15$ & 85 & $\mathrm{Co}(\mathrm{W})$ & $0.23^{*}$ & 1126 & 508 \\
$\mathrm{TiC} 70 / 14$ & 70 & $\mathrm{Fe}+14 \mathrm{Ni}$ steel, austenite & $0.23^{*}$ & 1268 & 398 \\
$\mathrm{TiC} 60 / 8$ & 60 & $\mathrm{Fe}+8 \mathrm{Ni}$ steel, martensite-bainite & $0.22^{*}$ & 1122 & 423
\end{tabular}

Values marked * are estimates. Source: CES 2005 Edupack.

Hardness and IFT tests were carried out on the INDENTEC 5030 SKV at 5 different loads $P$ between 2.5 and $50 \mathrm{kgf}$ at an indentation duration $10 \mathrm{~s}$. Additional universal hardness tests were produced on the Zwick Z2.5 apparatus at loads of 10,30 and $50 \mathrm{kgf}$ for the evaluation of the elasticity modulus $E$. Elasticity modulus was calculated according to the ISO 14577-1:2002 standard (Metallic materials - Instrumented indentation test for hardness and materials parameters).

The values of average indentation diagonals (Fig. 2) were obtained from at least six readings at each load level. The lengthening of cracks was observed with the increase of the applied indentation load (Fig. 3). Estimates of fracture toughness values were made at two different load $P$ levels of 30 and $50 \mathrm{kgf}$ for WC10, WC15 and T60/8 cemented carbides, and at 5 load levels 2.5, 5.0, 10.0, 30.0 and $50.0 \mathrm{kgf}$ for the T70/14 cermet. Optical investigation has shown that maximum available magnitude of the microscope $(\times 100)$ was not sufficient for crack length measurement in hardmetals WC10 and WC15 at loads lower than $30.0 \mathrm{kgf}$. Some expressions for the determination of fracture toughness have limited applicability.

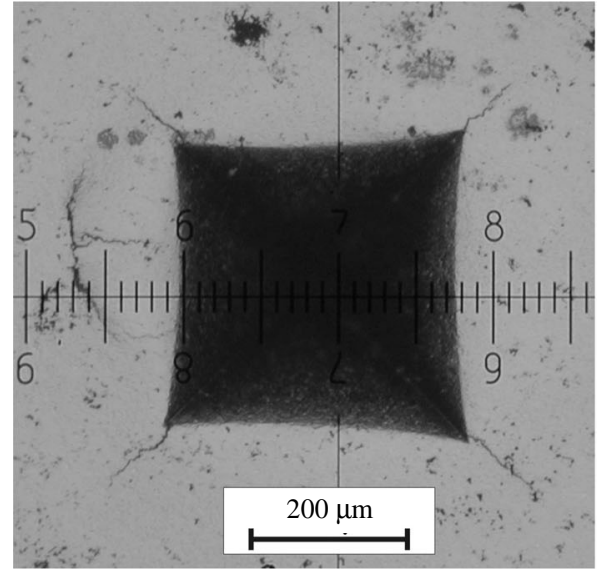

(a)

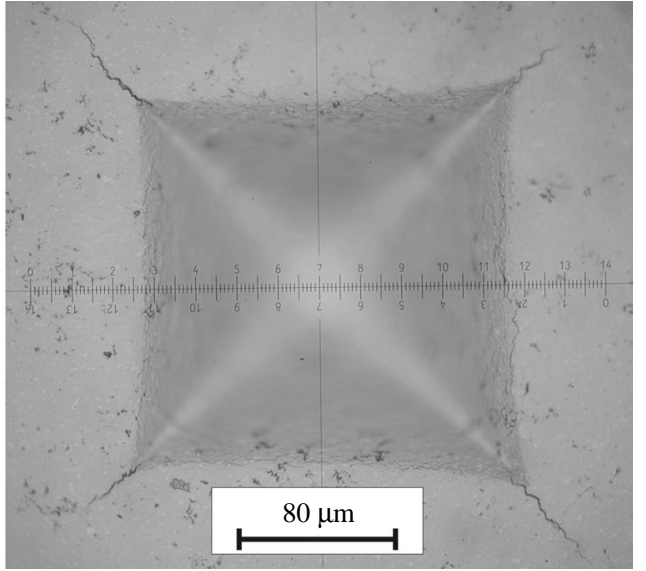

(b)

Fig. 2. Photographs of Vickers indentations of the T70/14-70 wt $\% \mathrm{TiC}$ (a) and Fe-14 wt $\%$ Ni cermets. 


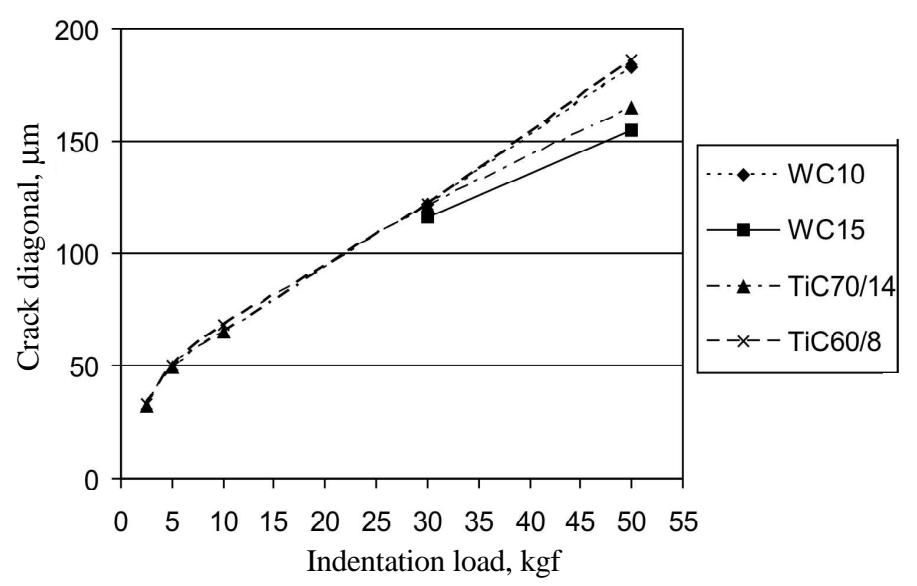

Fig. 3. Dependence of the crack diagonal length on the indentation load.

\section{RESULTS AND DISCUSSION}

For IFT calculations it is recommended to take into account the true (loadindependent) hardness of the material $\left[{ }^{1,8}\right]$. It is well known that the apparent hardness decreases with the increase of the indentation load and approaches a constant value at a relatively high load level (Fig. 4). Measured Vickers hardness
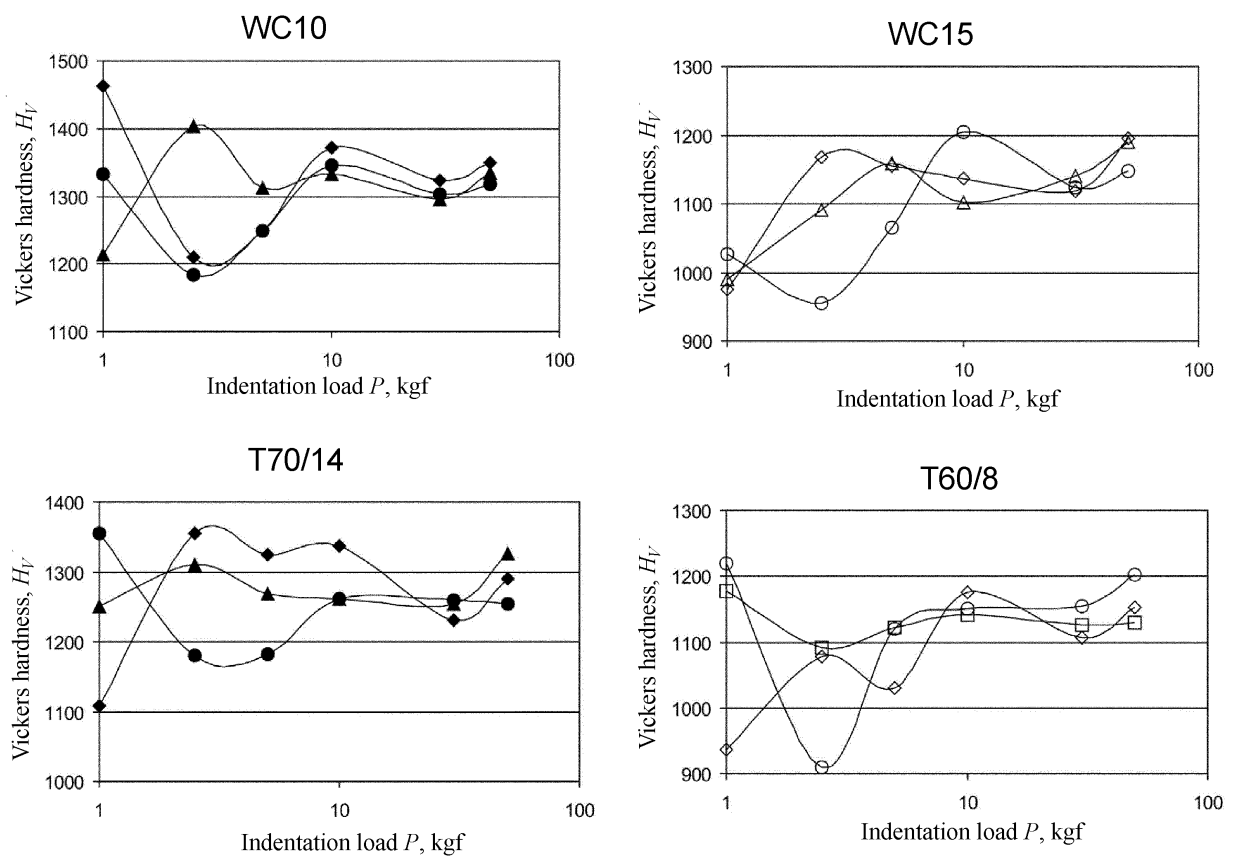

Fig. 4. Dependence of the Vickers hardness on the indentation load for tested cermets. 
$H_{V}$ was used in calculations. Equations for fracture toughness calculation were obtained in three different ways. The first way considers Palmqvist cracks as semi-elliptical cracks or uses the two-dimensional through-crack model (Table 2). The second way considers median cracks, based on the half-pennyshaped-crack model. The third way is based on curve-fitting technique.

Table 2. Equations for calculation of fracture toughness $\left(K_{\text {Ic }}\right)$ values from Vickers indentation crack systems

\begin{tabular}{|c|c|c|}
\hline $\begin{array}{l}\text { Eq. } \\
\text { No. }\end{array}$ & Equation & Ref. \\
\hline \multicolumn{3}{|c|}{ Palmqvist crack system } \\
\hline 1 & $K_{C}=0.0515 \frac{P}{c^{3 / 2}}$ & {$\left[{ }^{9}\right]$} \\
\hline 2 & $K_{C}=0.079 \frac{P}{a^{3 / 2}} \log \left(4.5 \frac{a}{c}\right)$ & {$\left[{ }^{10}\right]$} \\
\hline 3 & $K_{C}=0.035\left(\frac{l}{a}\right)^{-1 / 2}\left(\frac{H_{V}}{E \Phi}\right)^{-2 / 5}\left(\frac{H_{V} a^{1 / 2}}{\Phi}\right)$ & {$\left[{ }^{11}\right]$} \\
\hline 4 & $K_{C}=0.048\left(\frac{l}{a}\right)^{-1 / 2}\left(\frac{H_{V}}{E \Phi}\right)^{-2 / 5}\left(\frac{H_{V} a^{1 / 2}}{\Phi}\right)$ & {$\left[{ }^{12}\right]$} \\
\hline \multicolumn{3}{|c|}{ Median crack system } \\
\hline 5 & $K_{C}=0.0726 \frac{P}{c^{3 / 2}}$ & {$\left[{ }^{9}\right]$} \\
\hline 6 & $K_{C}=0.0752 \frac{P}{c^{3 / 2}}$ & {$\left[{ }^{13}\right]$} \\
\hline 7 & $K_{C}=0.129\left(\frac{c}{a}\right)^{-3 / 2}\left(\frac{H_{V}}{E \Phi}\right)^{-2 / 5}\left(\frac{H_{V} a^{1 / 2}}{\Phi}\right)$ & {$\left[{ }^{11}\right]$} \\
\hline 8 & $K_{C}=0.014\left(\frac{E}{H_{V}}\right)^{1 / 2}\left(\frac{P}{c^{3 / 2}}\right)$ & {$\left[{ }^{14}\right]$} \\
\hline 9 & $K_{C}=0.016\left(\frac{E}{H_{V}}\right)^{1 / 2}\left(\frac{P}{c^{3 / 2}}\right)$ & {$\left[{ }^{15}\right]$} \\
\hline 10 & $K_{C}=0.0725\left(\frac{P}{c^{3 / 2}}\right)$ & {$\left[{ }^{16}\right]$} \\
\hline
\end{tabular}


Table 2. Continued

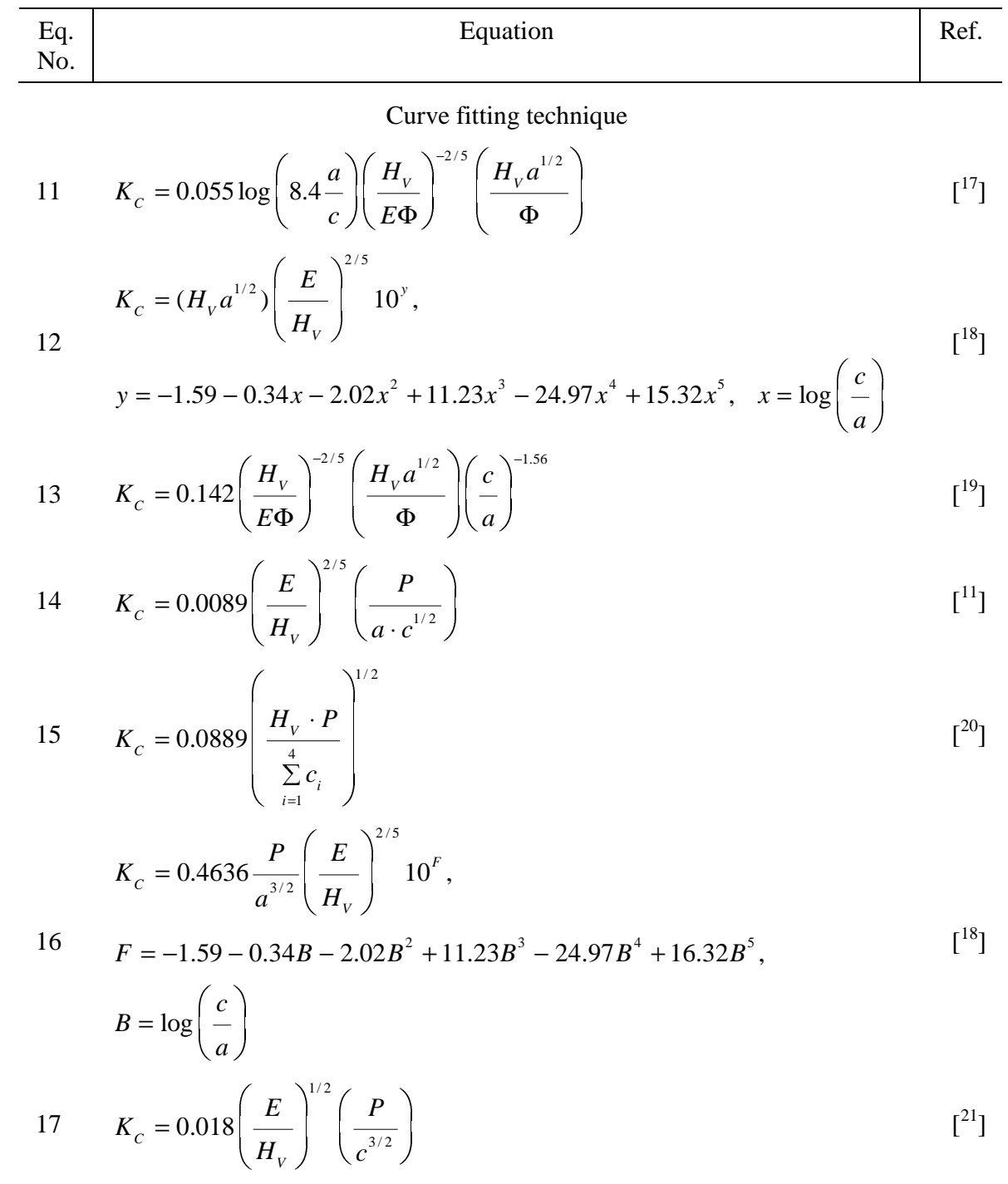

$\Phi$ is a constant, $\Phi \cong 3$.

Comparison of IFT values for WC10 hardmetal (at loads of 30 and $50 \mathrm{kgf}$ ) and for TiC70/14 cermet (at loads from 2.5 to $50 \mathrm{kgf}$ ), calculated using Eqs. (1)(17) are shown in Figs. 5 and 6, respectively. Fracture toughness $K_{\text {Ic }}$ varies from 10.247 to $30.394 \mathrm{MPa} \cdot \mathrm{m}^{1 / 2}$ for WC10 and from 5.387 to $31.44 \mathrm{MPa} \cdot \mathrm{m}^{1 / 2}$ for TiC70/14. From these results it is obvious that IFT depends on the indentation load (Figs. 7 and 8). 
A comparison of the obtained data with the published one is shown in Table 3. Results of the indentation fracture toughness measurement and calculation for WC15 hardmetal and TiC60/8 cermet are very similar to those of WC10 and TiC70/14 grades. Their behaviour is similar to the investigated materials. Hardmetal WC10 was chosen as a reference material because it is well studied and there is a lot of information available about it.

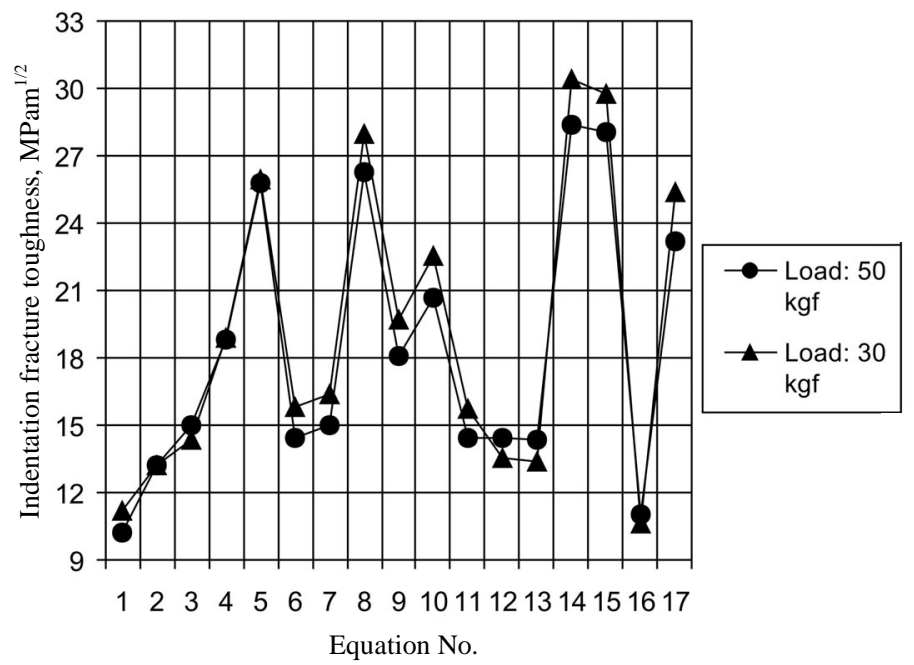

Fig. 5. Comparison of IFT values of the WC10 hardmetal, measured at 30 and $50 \mathrm{kgf}$ and calculated using Eqs. (1)-(17).

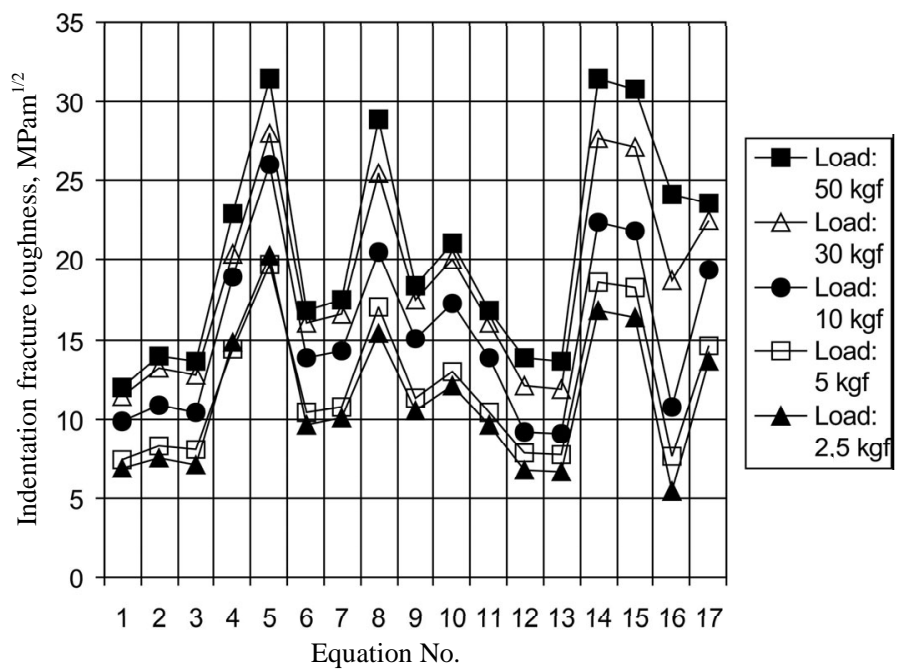

Fig. 6. Comparison of IFT values of the TiC70/14 cermet, measured at 2.5-50 kgf and calculated using Eqs. (1)-(17). 

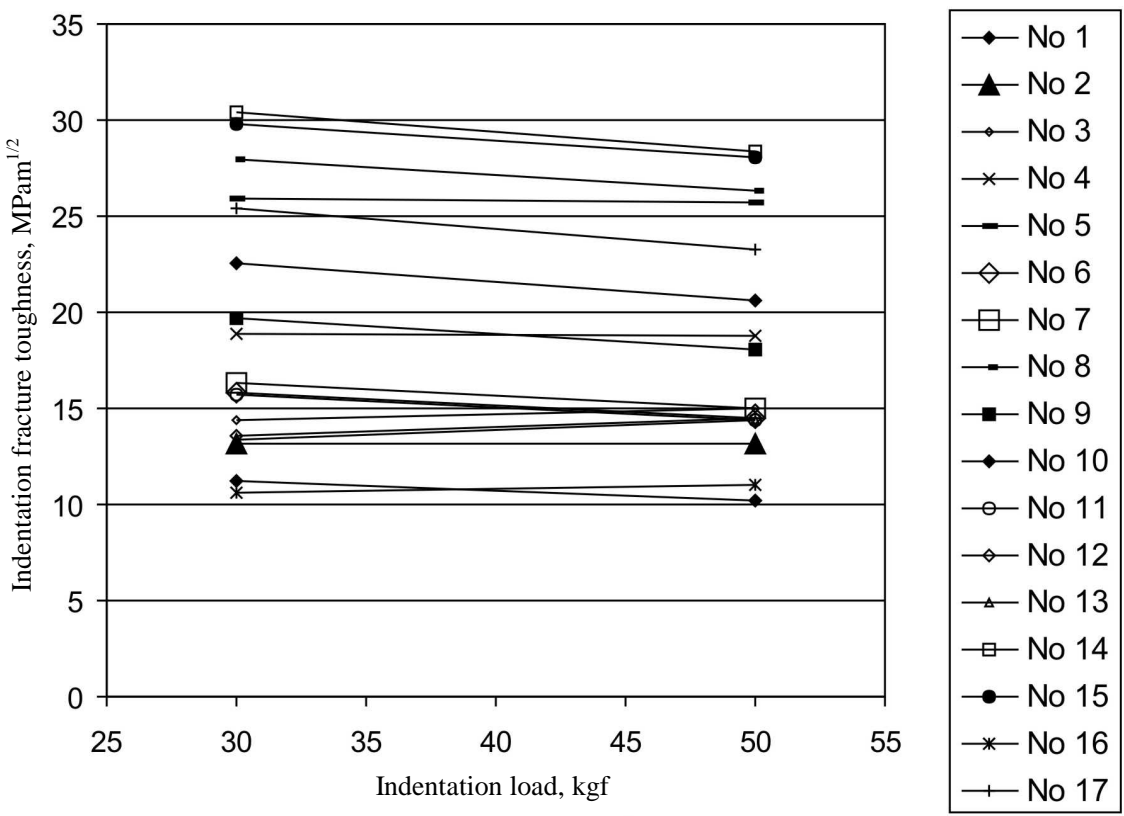

Fig. 7. Dependence of the calculated IFT values on the indentation load for WC10 hardmetal.

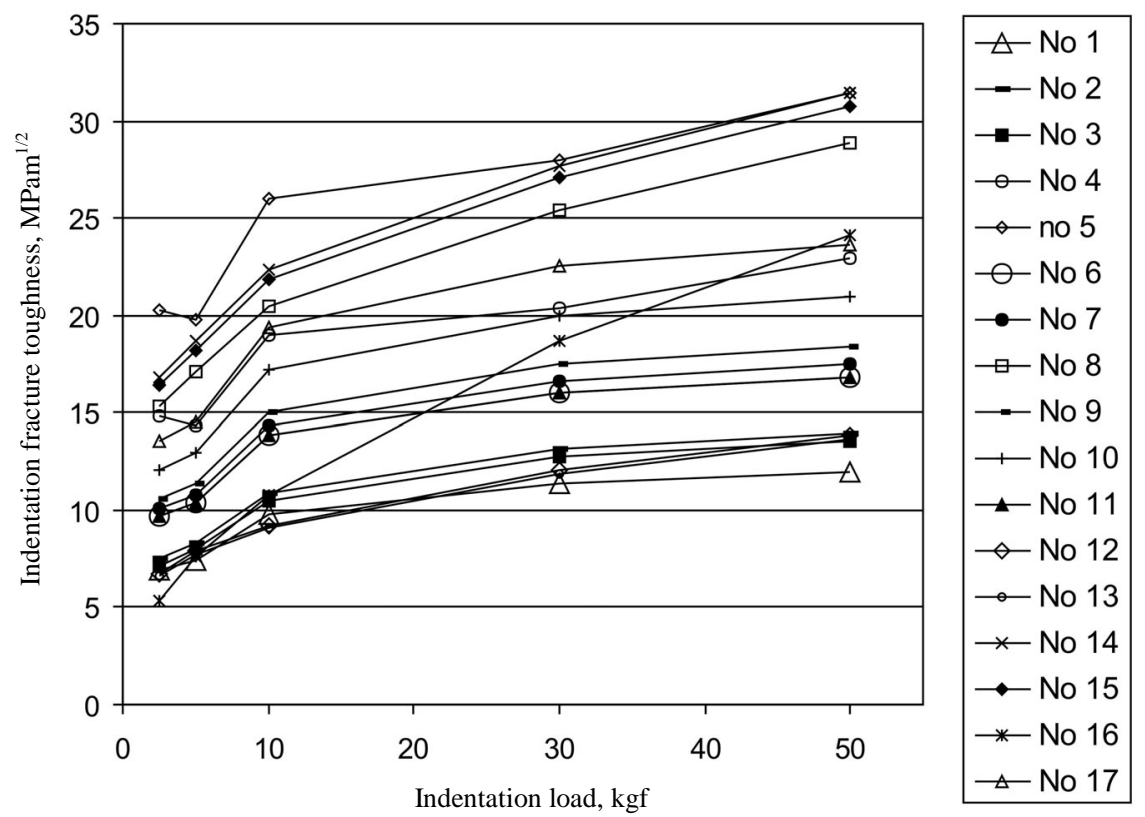

Fig. 8. Dependence of the calculated IFT values on the indentation load for TiC70/14 cermet. 
Table 3. Comparison of fracture toughness $K_{\mathrm{Ic}}\left(\mathrm{MPa} \cdot \mathrm{m}^{1 / 2}\right)$ values for $\mathrm{WC} 10$

\begin{tabular}{|c|c|c|c|c|c|c|c|c|c|c|}
\hline \multirow[t]{2}{*}{ Testing method } & \multicolumn{2}{|c|}{$\begin{array}{l}\text { Schubert } \\
\text { et al. }\left[{ }^{5}\right]\end{array}$} & \multicolumn{2}{|c|}{$\begin{array}{l}\text { Rosa } \\
\text { et al. }\left[{ }^{22}\right]\end{array}$} & \multicolumn{2}{|c|}{$\begin{array}{l}\text { Torres } \\
\text { et al. }\left[{ }^{4}\right]\end{array}$} & \multicolumn{2}{|c|}{ Scieszka $\left[{ }^{23}\right]$} & \multicolumn{2}{|c|}{$\begin{array}{l}\text { Current } \\
\text { study }\end{array}$} \\
\hline & $\min$ & $\max$ & $\min$ & $\max$ & $\min$ & $\max$ & $\min$ & $\max$ & $\min$ & $\max$ \\
\hline $\begin{array}{l}\text { SENB } \\
\text { (single edge notched } \\
\text { beam) }\end{array}$ & - & - & - & - & 8.6 & 10.5 & - & - & $13.4^{*}$ & $14.7^{*}$ \\
\hline $\begin{array}{l}\text { SEVNB } \\
\text { (single edge } \\
\text { V-notched beam) }\end{array}$ & - & - & - & - & 15.2 & 28.3 & - & - & - & - \\
\hline $\begin{array}{l}\text { SCF } \\
\text { (surface crack in } \\
\text { flexure) }\end{array}$ & - & - & - & - & 7.8 & 11.1 & - & - & - & - \\
\hline $\begin{array}{l}\text { CNB } \\
\text { (Chevron notched beam) }\end{array}$ & - & - & - & - & - & - & 11.61 & 13.78 & - & - \\
\hline $\begin{array}{l}\text { IFT } \\
\text { (indentation fracture } \\
\text { toughness) }\end{array}$ & 9.8 & 14.0 & 12.3 & 14.2 & 10.5 & 19.5 & 10.5 & 16.1 & 10.3 & 30.4 \\
\hline
\end{tabular}

Values marked * are estimates. Source: CES 2005 Edupack.

\section{CONCLUSIONS}

Most of the IFT equations, used in the present work, can be used by elaborating fracture toughness measurement data for WC- and TIC-based cemented carbides, with the exception of "extreme" equations (Eqs. (1), (5), (8), (14), (15), (16) and (17)). The equations, which are in a good agreement with fracture toughness data, received using the conventional testing methods (Chevron notched beam, SEVNB etc.) are: Eqs. (2), (6) and (12) by Evans, Charles and Wilshaw, Eqs. (3), (4) and (7) by Niihara, Eq. (9) by Anstis, Eq. (10) by Tanaka, Eq. (11) by Blendell and Eq. (13) by Lankford. Equation (17) by Japanese Standards Association can be used for TiC-based cermets only. Instrumented indentation testing is a sterling technique for the determination of mechanical characteristics of hardmetals (hardness, elastic modulus, yield stress etc.). TiCbased cermets are promising materials with reference to the fracture toughness compared with WC-based hardmetals; they tend to behave more plastically in spite of higher brittleness of the titanium carbide and increase of $K_{\mathrm{Ic}}$ with the rise of the indentation load.

\section{ACKNOWLEDGEMENT}

This research was supported by Estonian Science Foundation (grant No. 6163). 


\section{REFERENCES}

1. Ray, K. K. and Dutta, A. K. Comparative study on indentation fracture toughness evaluations of soda-lime-silica glass. Brit. Ceram. Trans., 1999, 98, 165-171.

2. Li, Z., Ghosh, A., Kobayashi, A. S. and Bradt, R. C. Indentation fracture toughness of sintered silicon carbide in the Palmqvist crack regime. J. Am. Ceram. Soc., 1989, 72, 904-911.

3. Vullo, P. and Davis, M. J. Comparative study of micro-indentation and Chevron notch fracture toughness measurements of silicate and phosphate glasses. J. Non-Crystall. Solids, 2004, 349, 180-184.

4. Torres, Y., Casellas, D., Anglada, M. and Llanes, L. Fracture toughness evaluation of hardmetals: influence of testing procedure. Int. J. Refract. Met. Hard Mater., 2001, 19, 27-34.

5. Schubert, W. D., Neumeister, H., Kinger, G. and Lux, B. Hardness to toughness relationship of fine-graned WC-Co hardmetals. Int. J. Refract. Met. Hard Mater., 1998, 16, 133-142.

6. Cook, R. F. and Pharr, G. M. Direct observation and analysis of indentation cracking in glasses and ceramics. J. Am. Ceram. Soc., 1990, 73, 787-817.

7. Smith, S. M. and Scattergood, R. O. Crack-shape effects for indentation fracture toughness measurements. J. Am. Ceram. Soc., 1992, 75, 305-315.

8. Gong, J., Wang, J. and Guan, Z. Indentation toughness of ceramics: a modified approach. $J$. Mater. Sci., 2002, 37, 865-869.

9. Lawn, H. R. and Fuller, E. R. Equilibrium penny-like cracks in indentation fracture. J. Mater. Sci., 1975, 10, 2016-2024.

10. Evans, A. G. and Wilshaw, T. R. Quasi-static solid particle damage in brittle solids - I. Observations, analysis and implications. Acta Metall., 1976, 24, 939-956.

11. Niihara, K., Morena, R. and Hasselman, D. P. H. Evaluation of $K_{\mathrm{Ic}}$ of brittle solids by the indentation method with low crack-to-indent ratios. J. Mater. Sci. Lett., 1982, 1, 13-16.

12. Niihara, K. A fracture mechanics analysis of indentation-induced Palmqvist crack in ceramics. J. Mater. Sci. Lett., 1983, 2, 221-223.

13. Evans, A. G. and Charles, E. A. Fracture toughness determinations by indentation. J. Am. Ceram. Soc., 1976, 59, 371-372.

14. Lawn, B. R., Evans, A. G. and Marshall, D. B. Elastic/plastic indentation damage in ceramics: the median/radial crack system. J. Am. Ceram. Soc., 1980, 63, 574-581.

15. Anstis, G. R., Chantikul, P., Lawn, B. R. and Marshall, D. B. A critical evaluation of indentation techniques for measuring fracture toughness - I. Direct crack measurements. J. Am. Ceram. Soc., 1981, 64, 533-538.

16. Tanaka, K. Elastic/plastic indentation hardness and indentation fracture toughness: the inclusion core model. J. Mater. Sci., 1987, 22, 1501-1508.

17. Blendell, J. E. The origins of internal stresses in polycrystalline alumina and their effects on mechanical properties. PhD Thesis. MTI Press, Cambridge, MA, 1979.

18. Evans, A. G. Fracture toughness: the role of indentation techniques. In Fracture Mechanics Applied to Brittle Materials (Freiman, W., ed.). ASTM STP 678, West Conshohocken, PA, $1979,112-135$.

19. Lankford, J. Indentation microfracture in the Palmqvist crack regime: implications for fracture toughness evaluation by the indentation method. J. Mater. Sci. Lett., 1982, 1, 493-495.

20. Shetty, D. K., Wright, I. G., Mincer, P. N. and Clauer, A. H. Indentation fracture of WC-Co cermets. J. Mater. Sci., 1985, 20, 1873-1882.

21. Testing method for fracture toughness of high performance ceramics. JIS R-1607, Japanease Standards Association, 1990.

22. Rosa, L. G., Amaral, P. M., Anjinho, C., Fernandes, J. C. and Shohoji, N. Fracture toughness of solar-sintered WC with Co additive. Ceram. Int., 2002, 28, 345-348.

23. Scieszka, S. F. Wear transition as a means of fracture toughness evaluation of hardmetals. Tribol. Lett., 2001, 11, 185-194. 


\title{
Kermiste purunemissitkuse määramise indenteerimismeetodite võrdlev analüüs
}

\author{
Fjodor Sergejev ja Maksim Antonov
}

Metallmaterjalide purunemissitkuse $\left(K_{\mathrm{Ic}}\right)$ määramiseks kasutatakse valdavalt nn Chevroni sälguga ja kompaktseid katsekehi, ümarsälguga tõmbeteimikuid jne. Kõik need meetodid on töömahukad katsekehade keeruka geomeetria ja kõrgete täpsusnõuete tõttu pingekontsentraatorile. Karbiidse faasi äärmise hapruse tõttu on ainult mõnda neist meetoditest võimalik kermiste puhul rakendada. Seetõttu on välja töötatud mitmeid indenteerimise purunemissitkuse (IPS) määramise meetodeid $\left[{ }^{1,2}\right]$. IPS seisneb teemantindentori surumises materjali pinda ja tekkinud pragude pikkuse ja geomeetria põhjal materjali $K_{\text {Ic }}$ väärtuse määramises. Eeliseks on meetodi lihtsus ja katse teostamise kiirus. Sel meetodil saadud tulemused sõltuvad oluliselt indenteerimise käigus tekkivate pragude eeldatavast tüübist (nn Palmqvisti või mediaan- ja radiaalpraod), arvutustes kasutatud valemitest ja veel mitmest tegurist $\left[^{3}\right]$. Artiklis on standardites ning varasemates uurimustes olevaid IPS-arvutusvalemeid kasutatud kermiste WC-Co ja TiC-Fe/Ni purunemissitkuse määramiseks ja saadud tulemusi on võrreldud teiste meetodite abil

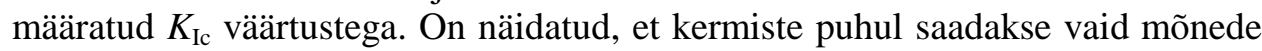
IPS arvutusteks soovitatud valemite abil usaldusväärseid tulemusi. 